\title{
Legal Constraints on the Indeterminate Control of 'Dangerous' Sex Offenders in the Community: The Dutch Perspective
}

\author{
Sanne Struijk \& Paul Mevis*
}

\begin{abstract}
In the Netherlands, the legal possibilities for post-custodial supervision have been extended considerably in recent years. A currently passed law aims to further increase these possibilities specifically for dangerous (sex) offenders. This law consists of three separate parts that may all result in lifelong supervision. In the first two parts, the supervision is embedded in the conditional release after either a prison sentence or the safety measure 'ter beschikking stelling' (TBS). This paper focuses on the third part of the law, which introduces an independent supervisory safety measure as a preventive continuation of both a prison sentence and the TBS measure. Inevitably, this new independent sanction raises questions about legitimacy and necessity, on which this paper reflects from a human rights perspective. Against the background of the existing Dutch penal law system, the content of the law is thoroughly assessed in view of the legal framework of the Council of Europe and the legal principles of proportionality and less restrictive means. In the end, we conclude that the supervisory safety measure is not legitimate nor necessary (yet). Apart from the current lack of (empirical evidence of) necessity, we state that there is a real possibility of an infringement of Article 5(4) ECHR and Article 7 ECHR, a lack of legitimising supervision 'gaps' in the existing penal law system, and finally a lack of clear legal criteria. Regardless of the potential severity of violent (sex) offenses, to simply justify this supervisory safety measure on the basis of 'better safe than sorry' is not enough.
\end{abstract}

Keywords: Dutch penal law, preventive supervision, dangerous offenders, human rights, social rehabilitation

\section{Introduction}

Similar to many other Western jurisdictions, ${ }^{1}$ the question how to control alleged dangerous offenders and to prevent them from reoffending is an ongoing debate in the Netherlands. This debate was once held primarily along the lines of preventive detention and incapacitation, particularly regarding mentally disordered offend$\mathrm{ers}^{2}$ and repeat offenders, ${ }^{3}$ while now the emphasis in Dutch penal law is (also) on supervision, again a similar trend as throughout Europe. ${ }^{4}$ As stated in the editorial of this special issue, the supervision itself is usually legally constituted either as an alternative to prosecution or custodial sentencing, or as (different forms of) an autonomous (community) sanction. In the Netherlands, both forms of supervision exist, and sometimes a supervision modality actually occurs in both, e.g. the modality of a ban to contact certain people (e.g. the victim) and community service. ${ }^{5}$ Yet, as in many other civil law jurisdictions, supervision within the Dutch system is not primarily perceived as autonomous sentencing but rather as 'alternative' sentencing, acting as the replacement of a suspended prison sentence or as part of a conditional release from imprisonment. ${ }^{6}$ The latter types of alternative, community sentencing are not new to the Dutch penal law system. Already in 1886, the legal possibility of conditional release after a prison sentence was introduced, followed by the introduction of the independent conditional sentence in 1915 and the introduction of the possibility of suspension of remand in 1926 . In practice, extensive use is made of all these supervision modalities.

Yet, as a result of many social and penological developments, supervision has been increasingly consolidated and extended in Dutch penal law in the past decades. Against the backdrop of both a culture of fear ${ }^{7}$ and a trend of public security together with a strong believe

M.J.F. van der Wolf, TBS veroordeeld tot vooroordeel (2012).

S. Struijk, De ISD in perspectief (2011).

F. McNeill and K. Beyens, Offender Supervision in Europe (2013).

G. Mclvor, K. Beyens, E. Blay \& M. Boone, 'Community Service in Belgium, the Netherlands, Scotland and Spain: A Comparative Perspective', 2 European Journal of Probation 82 (2010).

6. M. Boone and M. Herzog-Evans, 'Decision-Making and Offender Supervision', in F. McNeill and K. Beyens (eds.), Offender Supervision in Europe (2013), 51.

7. F. Furedi, Culture of Fear Revisited (2006). 
that penal law is an effective, managerial means to achieve this objective, ${ }^{8}$ not only existing supervision modalities were expanded, but new modalities were created as well. This emergence and consolidation of supervision in Dutch penal law was also significantly driven by several high-profile (legal cases against) (sex) offenders. This is not so much the punishment for their wrongdoing, but rather their post-custodial re-entry into society caused for public concern and upheaval. Notwithstanding the conditional nature of the (early) release of alleged dangerous ex-offenders, citizens are increasingly under protest concerning the presence of such an ex-offender in their neighbourhood. As a consequence of this 'not in my backyard' backlash, the Probation Services, as the implementing authority in regard to the re-integration, have trouble in finding mayors who are actually willing to let the re-integrating offenders stay in their community. ${ }^{9}$ Not only did this result in penal and civil lawsuits, e.g. regarding the disclosure of the ex-offenders residence, ${ }^{10}$ but it has also further intensified the debate on the re-integration, freedom of movement and privacy of dangerous (sex) offenders, on the one hand, and the social pressure under which the local administration and the Probation Services have to operate, on the other hand. This is a process in which the Probation Services as such have changed in recent years from an offender-support organisation into an offender-control organisation, ${ }^{11}$ making structured decisions on risk assessment. ${ }^{12}$ Meanwhile, the requisite balancing of interests between respecting (basic) rights of the dangerous ex-(sex)offender and the interests of victims and society seems to be inclined towards the latter interests. For example the Dutch legislator ${ }^{13}$ has responded to the tricky question if, how, when and where to re-integrate dangerous (sex) offenders after their custodial sentence, by extending the penal law system. Because the prevention of reoffending has become very important, if not the main goal of the Dutch sanction system, ${ }^{14}$ this legal extension is mainly aimed at

8. R. van Swaaningen, 'Public Safety and the Management of Fear', 9 Theoretical Criminology 289 (2005).

9. M. Boone, H.G. van de Bunt \& D. Siegel, Gevangene van het verleden (2014), and the prior study H.G. van de Bunt, N.L. Holvast \& J. Plaisier, Toezicht op zedendelinquenten door de politie in samenwerking met de reclassering (2011).

10. In this context, it is important to note that, unlike many other jurisdictions in and outside Europe - see T. Thomas, 'European Developments in Sex Offender Registration and Monitoring', 18 EJCCLCJ 403 (2010) - the Netherlands has no mandatory sex offender notification nor registration policy. Although the call (from citizens and politicians) to implement such policy is getting stronger, it still does not seem to happen, especially since recent research showed that in general the notification and registration with regard to sex offenders do not have (positive) effect on their recidivism (R.P. van der Horst, H.J.M. Schönberger \& C.H. de Kogel, Toezicht op zedendelinquenten. Effectiviteit en veronderstelde werkzame mechanismen van vormen van toezicht [2012]).

11. A. Menger and A.G. Donker, 'Bronnen van professionele effectiviteit', 38 Justitiële verkenningen 24 (2012)

12. J. Bosker, C. Witteman \& J. Hermanns, 'Structured Decisions about Dutch Probation Service Interventions', 60 Probation Journal 168 (2013).

13. In the Netherlands, the legislator is constituted by both the Government (including the King) and Parliament.

14. Struijk (2011), above n. 3. long-lasting, possibly even indeterminate forms of postcustodial release supervision. It is precisely this 'back door sentencing form' ${ }^{15}$ that this special issue focuses on. Therefore, the scope of this article is also limited to post-custodial release supervision modalities.

The first and important recent legal change concerning Dutch post-custodial supervision is the conversion of the unconditional early release after two-thirds of the prison sentence into a conditional release. Furthermore, new (restrictive) conditions were created and enshrined in law, and, finally, the unconditional release from the institution for the admission of dangerous mental disordered offenders with provision by the State (in Dutch the TBS 'met dwangverpleging') was curbed. Since 2013, an unconditional termination of this TBS safety measure is possible only if it is preceded by one year of conditional termination. In addition to these reinforcements of existing supervision modalities, a currently passed law - 24 November $2015^{16}$ - is focused on a threefold increase in the post-custodial supervision of dangerous (sex) offenders. First, by aiming to extend the length of parole after a prison sentence. Second, by aiming to extend the length of parole after the TBS measure. Last, by aiming to introduce a new independent supervisory safety measure as a preventive continuation of both a prison sentence and the TBS measure. All three parts of this law could result in life-long supervision. Given both the almost inherent severe restrictive nature of the supervisory conditions and the limited validity of assessment of dangerousness, ${ }^{17}$ the modality of (possibly) life-long supervision raises questions not only about the legal limits to it, but also about the transparency, fairness, and accountability of this type of sentencing and the decisions taken. ${ }^{18}$

Focusing on the currently passed - but not implemented yet - law on post-custodial release supervision in the Netherlands, this article will reflect on the aforementioned questions from a primarily human rights perspective. Before addressing this perspective in detail in Section 5, first the main features of the Dutch penal law system will be outlined, as well as its sentencing theory (Section 2). Then, the content of the law - particularly the third part - will be evaluated against the legal principles of both proportionality (Section 3 ) and less intrusive means (Section 4), in each case against the background of the already existing post-custodial supervision modalities. Finally, in the concluding remarks (Section 6), it is argued that the legal constraints are such that the new independent supervisory safety measure is not legitimate (yet).

15. N. Padfield, R. Morgan \& M. Maguire, 'Out of Court, Out of Sight?', in M. Maguire, R. Morgan \& R. Reiner (eds.), The Oxford Handbook of Criminology (2012), 955.

16. Stb. 2015,460

17. See e.g. A. Ashworth and J. Roberts, 'Sentencing: Theory, Principle, and Practice', in M. Maguire, R. Morgan \& R. Reiner (eds.), The Oxford Handbook of Criminology (2012), 866.

18. Padfield et al., above n. 15. 


\section{Outlines of Both the Dutch Penal Law System and the Underlying Sentencing Theory}

As briefly mentioned in the introduction, the concept of (preventive) supervision is not new to the Dutch penal law system and has even increased in recent years. This fits the contemporary penal policy in the Netherlands, driven by 'increasing political and public concern about the costs of imprisonment and of reoffending. ${ }^{19}$ Indeed, reducing reoffending has been strongly prioritised in Dutch sentencing in recent years. Regarding this prioritised goal, the Dutch penal law system has an abundant history of searching for such penal sentences so that reoffending can be reduced, and preferably prevented effectively. ${ }^{20}$ Particularly noticeable in this respect is the two-sidedness of this penal quest. In contrast to many jurisdictions, yet similar to, for example Germany, ${ }^{21}$ the Netherlands has a bifurcated, two-track system of retrospective, retributive penalties, on the one hand, and prospective, preventive measures, on the other hand. The penalties and measures differ significantly, at least in theory. In practice, though, the distinction is more subtle. In recent decades, the objectives of custodial penalties and safety measures have grown closer togeth$\mathrm{er}^{22}$ This is partly because the current Dutch sentencing theory is a compromise between the traditional NeoClassical theory and the subsequent Modern theory. ${ }^{23}$ Furthermore, one of the main arguments justifying the distinction between penalties and measures - in that a measure, unlike a penalty, does not aim to cause the offender to suffer - is rather unsatisfactory from both a pragmatic and a moral point of view as the offender does not actually feel whether the suffering is intentionally inflicted upon him. ${ }^{24}$ Nevertheless, to be able to understand the Dutch supervision modalities, it is important to clarify the differences between penalties and measures. These differences are generally described as follows.

19. F. McNeill, 'Community Sanctions and European Penology', in T. Daems, S. Snacken \& D. van Zyl Smit (eds.), European Penology (2013), 171 , at 172 .

20. Struijk (2011), above n. 3; S. Struijk, 'Punishing Repeat Offenders in the Netherlands: Balancing between Incapacitation and Treatment', 33 Behavioral Sciences \& the Law 148 (2015) and M.J.F. van der Wolf and M. Herzog-Evans, 'Mandatory Measures: Safety Measures?', in M. Herzog-Evans (ed.), Offender Release and Supervision: The Role of Courts and the Use of Discretion (2014), 193.

21. K. Drenkhahn, 'Secure Preventive Detention in Germany', 31 Behavioral Sciences \& the Law 312 (2013) and B.-D. Meier, Strafrechtliche Sanktionen (2015).

22. Van der Wolf and Herzog-Evans, above n. 20

23. C. Kelk and Ch. Haffmans, 'De strafrechtelijke maatregelen en het tanende tweesporenstelsel', in J.P. Balkema et al (eds.), Gedenkboek honderd jaar Wetboek van Strafrecht (1986), 333.

24. J.W. de Keijser, 'Never Mind the Pain, It's a Measure! Justifying Measures as Part of the Dutch Bifurcated System of Sanctions', in M. Tonry (ed.), Retributivism Has a Past: Has It a Future? (2011), 188.
The penalty is intended to retaliate against the offence that the offender committed in the past, stemming directly from fundamental notions of guilt, criminal responsibility and just deserts, which underlie the Dutch Neo-classical theory of punishment. ${ }^{25}$ Consequently, the penalty is not only strictly bound with proportionality limits, i.e. it may not be more intrusive than the offence itself or the extent of the offenders' guilt, but also bound with determined duration at the moment of sentencing. Dutch examples of a penalty are the prison sentence and the community service, both always with a fixed legal maximum duration at the moment of sentencing, although this may include (providing that the law allows it for certain crimes) the possibility of a conviction to lifetime imprisonment.

In contrast, the (safety) measure, imposed either in addition to a penalty or instead of it, is intended to safeguard society from future harm such as recidivism or dangerousness. ${ }^{26}$ Consequently, the measure is not strictly bound with proportionality limits, at least not related to the seriousness of the offence, and may take as long as necessary to reduce the offenders' risk and thereby effectively protecting society. ${ }^{27}$ This conceptualisation of the safety measure stems directly from the 'Modern' criminal law theory, also known as the 'social defence' movement, which was particularly influential in the beginning of the nineteenth century. ${ }^{28}$ Whereas the view of the Neo-Classical theory was mostly limited to both the offence and an appropriate retaliation for it, the Modern theory explicitly expanded that view to the offender. Prompted by the rise in (behavioural) scientific knowledge about the causes of crime, modern theorists explicitly beheld how the system could counteract these causes as effectively as possible in order to prevent crime. Moreover, individual-based deterrence became the central aim of Dutch penal sentencing, seeking to effectively protect society and prevent reoffending in the future ${ }^{29}$ Consequently, this called for a significant change of the Dutch Penal Code, which in accordance with the Neo-Classical theory was originally rather simple and uniform with a leading role for the penalty. Deciding to overstep the inherent boundaries of the penalty, and thereby 'ignoring' or 'overruling' the predetermined, proportionate sentencing as one of the major protecting principles of the Neo-Classical Theory, various safety measures were introduced in both the previous and the current century. ${ }^{30}$ Some of these measures are asset-related, e.g. the measure to confiscate illegally obtained benefits, or property-related, e.g. the measure to extract (dangerous) objects an offender used committing his offence or that were found during crimi-

25. Ibid. and Struijk (2011), above n. 3

26. See e.g. T. Kooijmans, Op maat geregeld? (2002) and Van der Wolf and Herzog-Evans, above n. 20.

27. According to Dutch penal law, though, penalties and measures can to a high extent be imposed simultaneously.

28. M.S. Groenhuijsen and D. van der Landen (eds.), De moderne richting in het strafrecht (1990).

29. Struijk (2011), above n. 3.

30. Van der Wolf and Herzog-Evans, above n. 20. 
nal investigations. Other safety measures, and more relevant to this study, are offender-related. And exactly as in many other Western world jurisdictions, ${ }^{31}$ Dutch safety measures are most frequently applied to a variety of alleged dangerous offenders.

In Dutch penal law, there are two examples of custodial safety measures dating back to the era in which the Modern theory was prevailing. First, the custodial safety measure for habitual offenders, adopted in 1929. ${ }^{32}$ Based on both objective and subjective legal criteria, a judge could decide whether alleged dangerous habitual offenders can be kept in preventive detention for a minimum of five and a maximum of ten years after execution of the initially imposed prison sentence. The detention as such was aimed at the incapacitation of the habitual offender or, if susceptible, at improvement of his behaviour. The central notion of dangerousness was defined as 'he who unceasingly and even professionally reoffends'. The legal criteria hardly further demarcated this notion, as well as the specific offender target group for imposing this safety measure, because these criteria required only past reoffending and 'a necessary and justified' preventive detention to prevent future reoffending. For these, and other fundamental reasons, the custodial safety measure for habitual offenders had, despite the adoption by Parliament, never formally taken effect and, consequently, the statutory regulation was withdrawn in 1988 .

The second and most renowned Dutch example of such a safety measure dating back to the Modern theory is the aforementioned TBS measure for mental disordered and (thus) dangerous offenders. The main reason for introducing this custodial TBS measure in 1928 was because neither the prison sentence nor the general psychiatry was able to adequately respond to this offender category. ${ }^{33}$ Although the TBS measure is designed as a custodial sanction, the actual execution takes place in specific treatment institutions aiming at one's rehabilitation. With the twofold justification of both public protection and treatment of the mental disordered offender, the still existing TBS measure is potentially and only for rather serious and violent crimes of indeterminate duration. In these cases, the measure can be prolonged indefinitely as long as, in the opinion of the judge, deprivation of liberty is still necessary because the offender's treatment has not (yet) diminished the danger he poses to society. Consequently, the TBS measure is the ultimate form of preventive detention in the Dutch penal law system. Of course, the life-long imprisonment is an ultimate sentence as well, yet not preventive by nature. Because of the divergent goals of the TBS measure and the life-long imprisonment - the first is aimed at rehabilitation, the latter is inherently not - the Dutch Supreme Court ('Hoge Raad') has ruled that both sanctions may not be imposed simultaneously. ${ }^{34}$

31. J. Pratt, Punishment and Civilisation (2002).

32. See extensively Struijk (2011), above n. 3 and Struijk (2015), above n. 20.

33. Van der Wolf, above n. 2

34. Dutch Supreme Court 14 March 2006, NJ 2007, 345.
The TBS measure has remained an accepted measure up until today because of continuing adjustments to the system. ${ }^{35}$ One of the most significant adjustments is that the previous medical model was replaced by a legal model, ${ }^{36}$ leading to the introduction of various legal constraints in 1988. Furthermore, it led to the introduction of the conditional, supervisory TBS measure in 1997. Within the framework of this alternative to the custodial variant, the court imposes several conditions behavioural and/or restrictive - to which the convicted offender must adhere. The Probation Services are responsible for monitoring the compliance. Violating the conditions may lead to custodial TBS. In order to reduce the number of imposed custodial TBS measures, this supervisory alternative has been strengthened in recent years, most importantly by raising the maximum duration from four to nine years. An opposite adjustment to the TBS sentencing scheme is that the custodial TBS measure in recent years may even be justified by solely the aim of public protection, subordinating the aim of treatment. Cost-effectiveness deliberations even led to the introduction of a so-called 'longstay-ward' as an official differentiation within the TBS domain in $1998 .{ }^{37}$ When a TBS detainee is placed on such a ward, the focus is no longer on treatment, or rather the treatment is no longer aimed at rehabilitation.

Rehabilitation has always been a recognised objective in Dutch penal law. Already in the past, the Dutch Supreme Court has given a broad interpretation to this objective, stating that the rehabilitation duty for the Government is not limited to the period after detention, nor exclusively aimed at a possible return to the Dutch society. ${ }^{38}$ Yet, over the past decades, the legal interpretation of rehabilitation has been subject to change. This is mainly because - although this objective is regulated by article 2 of both the Dutch Acts concerning the execution of imprisonment and the TBS order - it is not a constitutional right, in contrast to some other Western jurisdictions such as Germany. ${ }^{39}$ Moreover, the definition of rehabilitation in the Dutch Prisons Act is certainly not conclusive but leaves ample room for interpretation because for a long time the definition is as follows: 'the execution of the custodial sentence is made subservient to the offenders' rehabilitation as much as possible'.

Arising from the fact that rehabilitation is thus not an absolute right in Dutch penal law, the actual meaning and the content of this penal principle are to a large extent dependent on the prevailing sentencing theory and penal policy. In recent times, under the influence of the dominant theoretical concepts of risk society and utilitarian instrumentalism, rehabilitation is primarily

\footnotetext{
35. Van der Wolf and Herzog-Evans, above n. 20

36. Kelk and Haffmans, above n. 23.

37. H.J.C. van Marle and M.J.F. van der Wolf, 'Safety Measures in the Netherlands. The TBS', in M. Herzog-Evans (ed.), Transnational Criminology Manual (2010) 439.

38. Dutch Supreme Court 16 January 1987, NJ 1987, 405.

39. D. van Zyl Smit and S. Snacken, Principles of European Prison Law and Policy (2009) and Padfield et al., above n. 15.
} 
defined as risk-based. One could even argue that, in the Netherlands, rehabilitation is now more narrowly conceptualised as reducing reoffending, ${ }^{40}$ which calls for a strict control system and results in an authoritarian rather than an anthropocentric system. ${ }^{41}$

The most recent change in the legal definition of rehabilitation was the addition of two text parts in 2015. The first added phrase was that in the process of granting freedoms to detainees, such as granting a leave, one needs to take into account the safety of society and the interests of victims and survivors. This was undoubtedly triggered by some high-profile (sex) offenders, who escaped and reoffended during their leave. Second, the phrase was added that the execution of the custodial sentence is made subservient to the offenders' rehabilitation, depending on his behaviour during detention. This second change in the legal definition of rehabilitation is to a large extent attributable to the global 'What Works' movement, which has been firmly embraced in the Netherlands since the turn of the century. ${ }^{42}$ The movement has not only led to a growing interest in, and subsequent development of, various programmes for behavioural change, both within prison and as part of community sentences, but it has also made the detainee himself responsible for the actual extent to which is invested in his rehabilitation. On the basis of his proven willingness and efforts to participate in reducing reoffending and rehabilitation interventions, as well as the outcomes of risk assessment tools, his conditional release can be determined. More broadly, this principle of the offenders' individual responsibility also underlies the current detention regime in the Netherlands. Every inmate will start his detention in a basic programme, but (only) by exhibiting good behaviour he may be promoted to a plus programme with more freedoms and possibilities. ${ }^{43}$ Thus, in the current penal trend in the Netherlands, rehabilitation-oriented sanctions seem to be reserved for only the 'privileged' offenders who are expected to (and are able to) achieve success in this respect. $^{44}$

This penal trend holds certainly true for yet another custodial safety measure, the so-called ISD measure for repeat offenders ('inrichting voor stelselmatige daders'). ${ }^{45}$ Although the ISD measure may also be imposed in a supervisory variant, ultimately it is a custodial safety measure aiming to prevent future reoffending and harm. The main underlying concept of dangerousness differs significantly from the TBS measure. The ISD measure is specifically aimed at repeat offenders, who are not necessarily mentally ill - which by itself is

40. Mclvor et al., above n. 5 .

41. McNeill, above n. 19.

42. A.A. van den Hurk and P.Ph. Nelissen, "'What Works": een nieuwe benadering van resocialisatie van delinquenten', 5 Sancties 280 (2004).

43. Freedoms and possibilities, to some extent, can be seen as 'normal' conditions for an acceptable detention regime, e.g. increased opportunities for both education and receiving visitors, and the ability to be transferred to a limited secured regime.

44. Struijk (2011), above n. 3 and M.M. Boone, Our Own Rascals First (2012).

45. Struijk (2011), above n. 3 and Struijk (2015), above n. 20. not a legal criterion for imposing the ISD measure although in practice almost every repeat offender suffers from a mental disorder, or even a co-occurring disorder. ${ }^{46}$ The repeat offenders are rather perceived as dangerous because they continuously exhibit criminal behaviour, ${ }^{47}$ resulting moreover in (often addiction driven) 'highly visible', but rather 'light' urban crimes. The danger they pose to society is thus strongly nuisance related, which is something completely different from the danger the TBS offenders usually pose and the severe crimes they usually commit. ${ }^{48}$ Therefore, in contrast to the TBS measure, the ISD measure is legally of determinate duration with a maximum of two years. In contrast to the legislator's intentions, both judges and penitentiary workers appear to strive for as much treatment (of the individuals' behavioural problems and/or addiction and/or mental disorder) as possible. Consequently, the ISD measure constantly balances between incapacitation and treatment. ${ }^{49}$

Both the implemented safety measures TBS and ISD focus on a more or less specific offender category and are (partly) custodial by nature, depriving the offender of his or her liberty. That does not apply for the recently introduced (2012) community-based supervisory safety measure. It is an independent restraint sentence for a maximum of two years, by which the court can impose restrictive conditions on the offender such as a ban on contacting certain people, a ban on doing certain voluntary work, a duty to report to the Probation Services, a duty to undergo clinical treatment or, finally, a duty to move. The measure may be imposed for any committed offence, and its underlying dangerousness concept is defined in broad terms as restoring the public order and preventing harmful behaviour towards civilians, victims or witnesses. Moreover, violation of the conditions ordered by the court results in detention (equally ordered by the court) up to six months, which does not lift the validity of these conditions. In practice, this supervisory safety measure appears to be particularly imposed on offenders who have been sentenced to a prison sentence of less than a year, and who therefore legally do not apply for conditional release..$^{50}$

Altogether, arising from the notion that reoffending should be prevented, especially from dangerous offenders, various safety measures have been adopted in Dutch penal law. The offender-related safety measures are either custodial by nature, or involve non-custodial sentencing in the community. The sanction system was

46. N. Tollenaar and A.M. van der Laan, Monitor veelplegers 2013, WODC (2013).

47. One of the legal criteria for imposing the ISD measure is prior recidivism of at least three convictions in the last five years. It is because of this total number of three that the ISD measure has been referred to as 'a watered-down version of the American "three strikes" practice': Van Swaaningen, above n. 8.

48. Van der Wolf, above n. 2

49. Struijk (2015), above n. 20.

50. S. Meijer, ‘De gedragsbeïnvloedende en vrijheidsbeperkende toezichtsmaatregel als instrument in de strijd voor de maatschappelijke (schijn)veiligheid', in M.S Groenhuijsen et al (eds.), Roosachtig strafrecht (2013), 385 
recently once again expanded (and even completed, one might say) with both the introduction of various legal possibilities to execute the imposed sanction pending appeal and the possibilities to immediately arrest offenders who violate their conditions. To this extent the even more recently enacted law to expand post-custodial supervision fits well in the development of the Dutch sentencing scheme. In the following section, we will further discuss the content and legal framework of this latter law, with special reference to the independent supervisory safety measure.

\section{Legal Frameworks for Indeterminate Supervision: Evaluation of Proportionality}

The fact that community sentences must also be proportionate to the seriousness of the offence for which the sentence is imposed ${ }^{51}$ stems from the realisation that, despite their character of merely freedom restricting, these supervisory sentences quite often have a punitive content. In this respect, Van Zyl Smit and Snacken commented that 'all attempts to limit the rights of released persons beyond their sentence should be approached with considerable caution because they could amount to additional punishment'. ${ }^{52}$ This realisation, and development, is to be welcomed as supervision imposed with restrictive conditions such as an extended reporting requirement, or participation in a treatment programme, or an obligation to move, may indeed result in a harsher punishment than short prison sentences. Yet, it is certainly not easy to determine whether a supervisory sentence is in fact disproportionate. The international human rights framework within which this must generally be determined will be discussed in Section 5. In the present section, though, the legal framework of the presently discussed Dutch law is discussed, in order to determine whether or not it set limits to the extended supervision, and whether the three parts of the law are proportionate to the extent of the problem they should resolve. In this respect, attention is also paid to the pre-legislative justification of the draft law and its possible future practice.

As mentioned, the possibility of early release has already existed for a long time in Dutch penal law. The current legal framework constitutes a conditional release, as it has always been since 1886, except for an intervening period of twenty years when it was a standard release. The current conditional release is after two-thirds of the prison sentence, provided that it is an unconditional sentence of at least one year. The probationary period of the release may not last longer than the remaining onethird of the sentence, albeit with a minimum duration of

51. D. van Zyl Smit and A. Ashworth, 'Disproportionate Sentences as Human Rights Violations', 67 The Modern Law Review 541 (2004).

52. Van Zyl Smit and Snacken, above n. 39 one year for the probation of the general condition. By virtue of the general, standard prevailing condition, the convict should refrain from reoffending. In contrast, the more specific conditions, relating to the offender and his individual behaviour, do not have such a minimum term. By means of the first part of the currently enacted law, the Dutch legislator wants to change that. Although that may be understandable for reasons of consistency of legislation, the imposition of the general condition for one year is clearly much less invasive than the yearlong imposition of a specific condition aimed for behavioural change or restraint. ${ }^{53}$ However, this has not stopped Parliament from adopting an amendment that gives the court the possibility to extend the probationary period even continuously for up to two years. Consequently, any offender who has been sentenced by the court to an unconditional imprisonment of at least one year may therefore, in principle, be life-long supervised. Not only does he have to adhere to the imposed conditions for an indeterminate time, but he also has to fear for the execution of the remaining part of the prison sentence whenever he fails to adhere, although execution does require a separate court order.

The second part of the law specifically concerns the safety measure TBS for dangerous mentally disordered offenders. As stated earlier, this safety measure can be imposed both conditionally, maintaining the offender in the community, and unconditionally, detaining the offender in a secured treatment facility. In the unconditional custodial variety, the legislation allows the possibility of a conditional termination for reasons of a progressive and supervised re-integration. The probationary period of this conditional termination is set at a maximum of nine years. Until 2008, this period was three years. When the law was changed and the duration was set at nine years, the possibility of an indefinite probationary duration was discussed. ${ }^{54}$ However, the legislator deliberately chose not to introduce such an indefinite supervision modality, based on research showing that after nine years the chances of reconviction significantly decreases in relation to the preceding period. ${ }^{55} \mathrm{It}$ is therefore all the more remarkable that the Government by means of the enacted bill introduces such an indefinite duration anyway. The general justification is that, for certain crimes, a possibly indefinite probationary period of the conditionally terminated TBS measure is a harsh, yet necessary and proportionate means to guarantee both the fundaments of the TBS scheme and its termination. More specifically, the legislator justifies this new post-custodial supervision modality by highlighting new research showing that the percentage of repeat offenders with a very serious offence among sex offenders still increases for a long time after discharge

53. M.J.F. van der Wolf and S. Struijk, '(Levens)lang toezicht als zelfstandige maatregel: wordt nu echt de Rubicon overgestoken?', 6 Sancties 368 (2014).

54. Ibid.

55. E. Leuw, Recidive na de tbs, WODC (1999) and B.S.J. Wartna, S. el Harbachi \& L.M. van der Knaap, Buiten behandeling, WODC-Recidivestudies (2005) 
from the custodial TBS facility, and that adequate forms of supervision and guidance may be useful for the purpose of reducing the risk of recidivism longer than nine years after discharge. ${ }^{56}$

Yet, this justification has much to criticise ${ }^{57}$ For example the 'new' research findings relate to the long-term recidivism of TBS detainees who were released in the 1970 s and 1980s of the past century. Thus, it is highly questionable to what extent this has relevance for the future outflows and recidivism of TBS detainees. Furthermore, the latest legislative change in 2008 has not been evaluated, making it as yet unknown in how many cases the current maximum supervision period of nine years is actually fully exploited. Let alone that it can serve as a justification for introducing an even longer and possibly life-long supervision period. On the other hand, there are legal constraints, particularly the fact that it is up to a court to periodically review whether a renewal of the conditional termination is appropriate or not. Nevertheless, one may ask for a more solid justification in order to add such a modality of long, possibly life-long supervision to the TBS scheme, especially because this form of extended supervision is expected to occur only in exceptional cases. Considering the fact that in practice there seems to be little need for additional supervision after a probationary period of nine years, both legal scholars and legislative advisory bodies have labelled the proposal as unnecessary and premature.

To an even greater extent this holds true for the third proposal of the draft law. As briefly mentioned earlier, this proposal involves the introduction of an independent supervisory safety measure. This measure may also imply (life-)long supervision after the (un)conditional termination of the TBS measure, albeit not as contingent modality within the TBS scheme itself, but as an independent sanction. According to the intended legal framework, the procedure of this sentencing scheme is rather unique for Dutch penal law as the judicial decisions on imposition and execution are separated, both in time and authority. In this twofold procedure, the imposition of the new measure requires a concurrent imposition of a (un)conditional TBS measure or a (partly conditional) prison sentence of a maximum of four years or more. The latter possibility applies only for crimes against the inviolability of the body, thus particularly for (sexually) violent offenders. Indeed, this proposal seems to be focused primarily on sex offenders, aiming for public protection through their behavioural change and restraint. Public protection is also the general basis for the imposition of the measure, together with the aforementioned condition of a concurrent imposed sentence. Following the first stage of the imposition, the second stage of the twofold procedure is (of course) the execution. However, the supervisory safety measure is not

56. Kamerstukken I/ 2013/14, 33 816, n. 3, page 7 and Kamerstukken II 2013/14, 33816 , n. 6, page 28 .

57. As stated before by legal scholars such as S. Struijk, 'En nog meer en langduriger toezicht: de overheid als Rupsje Nooitgenoeg', 3 Sancties 137 (2014) and Van der Wolf and Struijk, above n. 53. executed immediately after the verdict. On the contrary, the execution will only start once the imposed TBS measure or prison sentence is (un)conditionally terminated. As this may take a while, usually for many years, the Dutch Government has wisely decided to make the execution a non-standard procedure. It requires another, separate judicial decision from the court, at the request of the Public Prosecutor, (soon) before the TBS measure or the prison sentence will end. It is then up to the court to decide whether the current situation is such that the previously imposed measure must actually be enforced. The legal requirements for execution are different, and more onerous than the requirements for imposition. The court may decide to execute the measure if there is a risk of recidivism relating to such an offence that would legitimise the imposition of this measure, or if enforcement is needed to avoid seriously damaging behaviour towards victims or witnesses. Both requirements are rather subjective by nature and call for a risk assessment. Remarkably, no multidisciplinary advice is needed, merely an advice from the Probation Services showing, inter alia, the results of the risk assessment. The use of such a risk assessment is not new to the Dutch sentencing scheme, as it already applies to other (existing) safety measures, such as the aforementioned ISD measure for repeat offenders. ${ }^{58}$ However, in addition to the fact that the (predictive) validity of those risk instruments is still highly criticised, ${ }^{59}$ this criticism may apply even stronger to the new supervisory measure because of its possibly indefinite duration, and the fact that the actual decision to execute the measure is legally immediately enforceable. However, a separate appeal may be lodged against this second decision.

Only in this second phase of the procedure - the execution - does the court further specify both the duration and the content of the measure. As to the duration of the measure, the court may order the enforcement of the measure for a period of two, three, four or five years. Upon expiry and based on the aforementioned execution requirements, the duration may be extended unlimited by the court for another two, three, four or five years. Thus, the supervisory safety measure may last indefinitely. On the other hand, the legal framework guarantees in any case that a judge periodically assesses whether an extension is appropriate. As to the content of the measure, the court may impose fourteen conditions, whether or not combined. Those conditions are explicitly mentioned in the legislation. In addition, the court may also ordain electronic monitoring. For the most part the fourteen conditions are restrictive, such as a notification requirement and a ban to have contact with certain persons. Others are therapeutic, such as a duty to participate in treatment. The court can order this condition with or without a clinical admission. In the first case, the admission lacks the consent of the offender; he or she is not so much restricted in his or

58. Struijk (2011), above n. 3 and Struijk (2015), above n. 20.

59. M. Moerings, 'Persistent Offenders', in M. Boone and M. Moerings (eds.), Dutch Prisons (2007), 187. 
her freedoms but rather deprived of his or her liberty. A second reason why the supervisory safety measure may turn into deprivation of liberty is the fact that alternative detention with a maximum duration of six months per (extended) term will occur whenever a condition is breached. It is because of these legal possibilities of deprivation of liberty that in our view this measure must comply with the test required by Article 5 ECHR. Both this test and the question whether the measure actually does comply will be addressed in detail in Section 5 .

The aforementioned conditions are as such not new to the Dutch penal law system. Already in the framework of many supervision modalities, it is possible to set these conditions. ${ }^{60}$ The draft law does introduce three new conditions, though. A ban to do certain voluntary work, a ban to live in certain areas and the opposite duty to move. These conditions are clearly very restrictive by nature, as well as clearly driven by the (housing) problems of re-integrating sex offenders. The same is reflected in the pre-legislative justification, in which the Dutch Government explicitly refers to the added value of the measure. ${ }^{61}$ According to the Government, this added value is especially true for crimes such as possessing child pornography. As this is not considered to be a serious offence, it may 'only' legitimise a custodial TBS order for a maximised period of four years. Therefore, according to the legislator, additional supervision would be required by means of the proposed supervisory safety measure.

However, in light of the proportionality test, one may actually question the added value. The foremost concern is the fact that in practice there seems to be limited need for this measure. An impact analysis showed an expected annual execution of the proposed measure regarding thirteen to thirty-three sex offenders and fourteen to twenty-nine violent offenders. ${ }^{62}$ Out of a total Dutch population of nearly seventeen million inhabitants, this is quite a small number. Together with the expected success rate of $5 \%$ to $30 \%$, and the expected pragmatic and financial bottlenecks in the enforcement of this possibly life-long supervision, the question arises as to whether the measure is proportionate to the extent of the problem. This is especially true when one takes into account the fact that the public upheaval resulting from the sex offenders' re-integration occurs only in a small minority of cases and generally disappears quickly. ${ }^{63}$ Therefore, the above-mentioned question and legal issue will most likely lead to reluctance among the judiciary, perhaps not so much with respect to the imposition of the measure, but rather with regard to the subsequent decision whether the measure must be executed. As with most other forms of risk-based sentencing, the judiciary bears great responsibility to balance the various interests in a just manner. As Henham stated eloquently, 'the risk management issue must be

60. F.W. Bleichrodt, P.A.M. Mevis \& B. Volker, Vergroting van de slagvaardigheid van het strafrecht; een rechtsvergelijkend perspectief (2012).

61. Kamerstukken I/ 2013/14, 33 816, n. 3.

62. Ibid

63. Boone et al., above n. 9 . resolved by the judiciary who remain the unenviable arbiters of predicted dangerousness' ${ }^{64}$ With regard to the Dutch safety measure for repeat offenders - the aforementioned ISD measure - judges appear to be quite capable to weigh the interests well and to sentence in such a way that it is proportionate to both the extent of the problem and the future risk the offender poses. ${ }^{65}$ Nevertheless, the level of dangerousness of repeat offenders differs significantly from sex offenders and violent offenders, for example because of the different degrees of the offences committed by these offenders: petty crime versus sex offences and violent offences.

But no matter how far-reaching the consequences of the latter crimes are, this does not say anything about the prediction whether a convicted sex offender or violent offender will truly reoffend in future. And that prediction is beset with various obstacles, including a lack of precision and predictive value. ${ }^{66}$ In that respect, it can be strongly criticised that the legal framework on the new supervisory safety measure does not require a multidisciplinary advice to the court in order for them to impose or execute the safety measure. Only an advice of the Probation Services, stating the outcomes of the risk assessment, is required or, if the court sets a condition that involves treatment or inclusion in a forensic care facility, a medical certificate. This meagre requirement pinches even more so when one considers the two aforementioned, rather subjective requirements for executing the supervisory safety measure. Especially the required necessity to avoid seriously damaging behaviour towards victims or witnesses will be difficult to scientifically support. As long as this continues, it contributes to our previously stated view that the enacted law is premature.

Another argument for that opinion is the fact that, according to the Dutch sentencing theory, a safety measure is proportionate only if it is not merely imposed in the public interest, but also to serve, at least to a certain extent, the individual interest. ${ }^{67}$ Yet, the latter interest is clearly missing in the law presently discussed. Naturally, the aim that the (sex) offender can carefully and gradually return to society may also be of his individual interest, as explicitly indicated in the pre-legislative justification, but that strongly depends on the content of the supervision. Will the supervision be truly focused on the completion of the offenders' rehabilitation and behavioural change, or predominantly the control of the offender? On that imperative question, the legislator has not said anything yet. Given the fact that this safety measure may also be imposed on offenders who are not mentally disturbed - those who have not been sentenced to the TBS measure, but instead to a

64. R. Henham, 'The Policy and Practice of Protective Sentencing', 3 Criminology and Criminal Justice 57 (2003).

65. Struijk (2011), above n. 3 and Struijk (2015), above n. 20.

66. N. Morris and M. Miller, 'Predictions of Dangerousness', 6 Crime and Justice 1 (1985) and L.M.J. Simon, 'An Examination of the Assumptions of Specialization, Mental Disorder, and Dangerousness in Sex Offenders', 18 Behavioral Sciences \& the Law 275 (2000).

67. W.P.J. Pompe, Beveiligingsmaatregelen naast straffen (1921) 
prison sentence - one may fear that the focus will be on control. Research concerning supervision shows, however, that control is effective only when combined with counselling, treatment, social support and a focus on 'the realisation of meaningful lives' instead of 'the prevention of risks' ${ }^{68}$ An important side note, though, is that it is still unknown how effective supervision will be if it takes many years, let alone life-long. ${ }^{69}$ The lack of prospect as a result of the indefinite duration of the proposed supervisory safety measure may very well diminish these effects. ${ }^{70}$ If so, the new measure is not likely to contribute to public safety. Given the equally existing fear of a self-fulfilling prophecy and the possibility that this supervisory measure may isolate the convicted (sex) offender, which leads to dangerous situations, ${ }^{71}$ the measure may easily have a counterproductive effect. The necessity of this measure is therefore anything but clear.

\section{Legal Gaps? An Evaluation of Alternative, Less Restrictive Means}

In order to protect society, a further step in the supervision of (conditionally) released inmates may very well be legitimate, even if it results in an (even more severe) human rights restriction, provided, though, that other less restrictive means (LRM) for supervision are (proved to be) insufficient. If this element is not addressed properly, community sanctions tend to be infected by what is known as the problem of 'Net Widening': new sanctions, introduced as an alternative, causing a wider and stronger net of social control. ${ }^{72}$ In the pre-legislative justification of the draft law, the legislator proclaims that the proposed supervisory safety measure complies with this LRM test. ${ }^{73}$ In fact, the critique with regard to - the supposed failure of - the current penal sanctions concerning the offender category of dangerous sex and/or violent offenders is one of the main arguments of the legislator to underline the necessity of the new supervisory measure. According to the legislator, the most pressing supervision 'gaps' are threefold. ${ }^{74}$

See e.g. A. McAlinden, "The Use of "Shame" in the Reintegration of Sex Offenders', 45 British Journal of Criminology 373 (2005); Van der Horst et al., above n. 10 and B. Weaver, 'Control or Change? Developing Dialogues between Desistance Research and Public Protection Practices', 61 Probation Journal 8 (2014).

69. Van der Horst et al., above n. 10.

70. Van der Wolf and Struijk, above n. 53.

71. Nationaal Rapporteur Mensenhandel en Seksueel Geweld tegen Kinderen, Isoleren zedendelinquenten is niet de juiste weg (2013).

72. E. Reznichenko, 'Cost-Effective Criminal Enforcement: A Law and Economics Approach' (Doctoral dissertation on file at the EUR, Rotterdam) (2015).

73. Kamerstukken // 2013/14, 33 816, n. 3

74. Ibid.
First, the problem of mentally disturbed suspects of whom the Public Prosecutor demands a custodial TBS order but who refuses to cooperate with the required multidisciplinary assessment, causing the judiciary to struggle with the dilemma whether they can still impose a TBS order or not. ${ }^{75}$ Although the Dutch Supreme Court has ruled that, in such circumstances, a court may indeed impose a TBS order, provided that the disorder can be sufficiently established otherwise, ${ }^{76}$ in practice this infamous trend among mentally disturbed suspects has already resulted, and even still results, in a strong decrease in the numbers of imposed TBS orders. ${ }^{77}$ Because many of these suspects are sentenced with a prison sentence instead, the duration of their postrelease supervision is usually not very long. In an attempt to tackle this troubling problem, the legislator has made the new supervisory measure possible not only for offenders who have been sentenced with a TBS order but also for violent offenders who have been sentenced for an offence punishable (with some exceptions) with a prison sentence of four years or more.

The second supervision 'gap' that the legislator aims to fill by introducing this supervisory measure is the maximised length of the conditional TBS order. Under existing law, this conditional order may last for no longer than nine years. The third supervision 'gap' relates to another TBS variant, the maximised custodial TBS order. In contrast with the indeterminate custodial TBS order, this maximised variant may last no longer than four years and may only be imposed for non-violent offences. The law rules that if the court decides to prolong the custodial TBS order, exceeding the four-year term, the relevant violent offence must be explicitly justified in the judgement. Based on the prevailing doctrine of the Court of Arnhem-Leeuwarden - the highest court in the Netherlands in cases concerning the prolongation of TBS orders - the extension judge had a wide discretion with regard to the assessment of the maximisation of the TBS order. ${ }^{78}$ In other words, this judge could independently assess whether there was a violent crime, resulting in a maximised duration of the TBS measure. The extension judge was even allowed to deviate his judgement from the initial sentence whereby the TBS measure was imposed. However, in 2012, the European Court of Human Rights (ECtHR) disapproved of this doctrine. ${ }^{79}$ The Strasbourg Court ruled that whenever the TBS order was imposed, the judgement must justify whether the offender has committed a violent crime. In the absence of such a justification, the extension judge may not assess independently if the TBS order was imposed for a violent crime and consequently if this order is maximised or indeterminate.

M.J.F. van der Wolf, E.M. Gremmen, H.J.C. van Marle \& P.A.M. Mevis, 'Worstelen met de weigerende observandus', 74 Delikt en Delinkwent 775 (2012).

76. Dutch Supreme Court 22 May 2012, ECLI:NL:HR:2012:BW6184.

77. DJ, Forensische Zorg in getal 2010-2014 (2015).

78. Court of Appeal Arnhem 30 May 2011, LJN BQ6616.

79. ECtHR, Van der Velden v. the Netherlands, Applic. No. 21203/10, 31 July 2012. 
According to the ECtHR that would not only be in conflict with Dutch legislation but also with the legal certainty as required by Article 5(1) ECHR.

At first glance, the three arguments made by the legislator seem to be valid. However, to our opinion, ${ }^{80}$ there is much to object. Each of these arguments directly relates to the TBS sentencing scheme, stating that it is ineffective in order to protect society from dangerous released offenders. Yet, instead of a thorough reform of the existing scheme of this safety measure - if needed at all - the legislator decided to introduce a new safety measure. Why such a radical change in the sentencing scheme whereas a less stringent solution may be on hand? Or, to quote Brems and Lavrysen, why to use a sledgehammer to crack a nut ${ }^{21}$ Moreover, it is strange that precisely the only part of this threefold law that does seek to directly change the TBS system - i.e. the earlier mentioned second part of the draft law, aiming to alter the maximised conditional termination of the TBS order in an indeterminate duration - is at odds with the equally introduced supervisory safety measure. It is redundant to abolish the maximum term of conditional TBS termination, making the supervision possibly lifelong, while at the same time introducing a separate safety measure that also allows for life-long supervision after termination of the TBS order. Surely at least the evaluation of this already drastic change in the TBS scheme should be awaited before a new measure is added to the sanction system. The ISD measure for repeat offenders shows that it is necessary to await such an evaluation of existing measures instead of hastily introducing a new measure. $^{82}$

This criticism with regard to the new supervisory safety measure based on the LRM test also holds true when one recalls the first part of the law - the possibility to continuously extend the probationary period associated with the conditional release from imprisonment, making it possibly life-long. Therefore, also in terms of a prison sentence, indeterminate supervision of dangerous offenders will be possible, which again undermines the legislator's argument of disturbing supervision 'gaps'. In fact, when one looks at the Dutch sentencing scheme as a whole, it appears that in the past decades there has been truly a rise of (preventive) supervision modalities. $^{83}$ By introducing new and strengthening existing both front door and back door supervision modalities, the Government aims to achieve a more effective criminal justice system. ${ }^{84}$ But even outside the criminal justice system, if for some reason the penal foundation for a legitimised supervision ends, there are opportunities from other legal jurisdictions to protect society or to enhance a good rehabilitation of the offend-

80. Largely following Van der Wolf and Struijk, above n. 53.

81. E. Brems and L. Lavrysen, “' Don't Use a Sledgehammer to Crack a Nut": Less Restrictive Means in the Case Law of the European Court of Human Rights', 15 Human Rights Law Review 139 (2015).

82. Struijk (2011), above n. 3

83. Van der Wolf and Struijk, above n. 53 and Bleichrodt et al., above n. 60 .

84. Bleichrodt et al., above n. 60 . er. For instance, in the presence of a disorder from which danger arises, the possibility exists to place someone into a psychiatric hospital. If the present draft law on Forensic Care is adopted, this possibility will belong to the jurisdiction of the criminal court so that it can better meet the end of a penal sentence. Together with another draft law on Mandatory Mental Health, this possibility will also allow for mandatory medication or supervision modalities. ${ }^{85}$ Finally, the law allows for mayors to ask in civil proceedings for imposing supervisory conditions on supposedly still dangerous exoffenders who return in the mayor's community. ${ }^{86}$

\section{Evaluation from a Human Rights Perspective}

Given the sharp increase of supervision in many Western jurisdictions, the stringent character and the (possibly life-)long-term nature thereof, and the attendant questions of human rights considerations, one would expect a clear human rights framework. But already on the Dutch national level, there is no legal or constitutional framework to test these kinds of penal developments because the Constitution (Art. 120) forbids judges to declare a law in breach of the constitution. Nevertheless, considering the fact that according to the same Constitution (Art. 94) international (human rights) law - more precisely, binding treaty provisions and resolutions by international organisations - takes precedence over national law, one would expect an international catalogue of criteria. Yet, the opposite is true. Unlike the penal concept of (preventive) detention, for which the directly applicable and legally binding framework of Articles 3 and 5 ECHR applies to assess whether the detention is legitimate and whether its execution is humane, such a framework is lacking with regard to the penal concept of (preventive) supervision. As set forth in the editorial of this special issue, there is no clear, uniform legal framework to assess whether supervision is a legitimate punishment as such, but rather a heterogeneous framework. Based on the description of this legal framework of the Council of Europe in the editorial, we will evaluate next whether the currently enacted Dutch law - more specifically the new supervisory safety measure - is legitimate or that it may form a breach of a certain (human) right.

With respect to the non-legally binding recommendations within the framework of the Council of Europe, and relevant to the present Dutch draft law, the current European Rules on Community Sanctions and Measures $(\operatorname{Rec}(2000) 22)$ merely states that a community

85. J. Legemaate et al., Thematische wetsevaluatie gedwongen zorg (2014).

86. C.E. Huls and J.G. Brouwer, De terugkeer van zedendelinquenten in de wijk (2013). However, this is not allowed during a conditional release (Court Midden-Nederland 6 November 2013, ECLI:NL:RBMNE: 2013:5494) or if the conditions are too severe (Court of Appeal Den Bosch 5 March 2013, ECLI:NL:GHSHE:2013:BZ3488). 
sanction or measure ordinarily shall not be of indeterminate duration. ${ }^{87}$ This provides some grounds and flexibility for the justification of both the supervisory safety measure and the two other parts of the Dutch law, all of which supervisory modalities may indeed be of infinite length. However, in principle, the duration of the modality is actually determined in advance by the judge, after which it can be renewed infinitely. In this respect, it is also important that not only the aforementioned recommendation but also other applicable recommendations, such as the recently adopted recommendation with regard to electronic monitoring $(\operatorname{Rec}(2014) 4)$, call for proportionality, defining this principle as proportionate to the seriousness of the committed offence, not the alleged offenders' risk and danger.

The proportionality requirement for introducing and implementing a national modality of supervision also derives from Article 2 Fourth Protocol ECHR, ${ }^{88}$ a second 'entrance' for assessing the new supervisory safety measure. The implication of this requirement that an interference must be necessary, i.e. that it corresponds to a pressing social need and is proportionate to the legitimate aim pursued, is also true for assessing the extent to which a supervisory modality infringe on the offenders' right to respect for his private and family life, his home and his correspondence under Article 8 ECHR. This assessment is certainly relevant to the various supervision conditions permitted under the Dutch draft law, which inevitably involve a fundamental restriction of one's freedom of movement and privacy. This certainly applies for the restrictive conditions mentioned in the previous sections such as restraining orders concerning certain areas or to have contact with certain people, a ban to do certain voluntary work, a ban to live in certain areas and the opposite duty to move from a certain area. In the pre-legislative justification of the proposed supervisory safety measure, the Dutch Government justifies explicitly that, and why, these conditions, as well as the proposed measure as such, may very well satisfy the aforementioned necessity requirement. ${ }^{89}$ Yet, to our opinion, the adduced justification that the new possibility of restrictive conditions for a (life-)long period will provide additional customisation possibilities for achieving a controlled and gradual rehabilitation of certain dangerous offenders is not convincing enough, especially because in recent years this argument is already used very often to extend the range of conditional supervisory modalities. ${ }^{90}$ It does stop at some point. Especially considering the fact that in practice little need seems to exist for the introduction of such a severe (life-)long supervisory safety measure, as discussed in Section 3. Not only do the impact analysis and expected success rate concerning the supervisory

87. C. Morgenstern, 'European Initiatives for Harmonization and Minimum Standards in the Field of Community Sanctions and Measures', 1 European Journal of Probation 128 (2009).

88. Again, for an elaborated description of this legal framework, see the editorial of this issue.

89. Kamerstukken // 2013/14, 33 816, n. 3.

90. Struijk (2014), above n. 57. safety measure show rather low numbers, but moreover, and perhaps even more important, not all executive authorities are keen on actually implementing this measure. This specifically holds true for the judiciary. In the Netherlands, the judiciary is inclined to exert strict control over the proportionality in the imposition and execution of sanctions, not only by the criminal court, ${ }^{91}$ but by the civil court in summary proceedings as well. In a recent example of such proceedings, the civil court explicitly ruled that two of the restrictive conditions imposed on a conditionally released offender - an area restraining order with associated electronic monitoring for five municipalities - were disproportionate and therefore needed to be suspended. ${ }^{92}$

To sum up, the legal notions of proportionality and LRM certainly do provide an entrance for both national courts and the ECtHR, to decide whether the application of certain restrictive conditions in individual cases is acceptable. Nevertheless, as mentioned, Dutch developments do not differ from the general 'line' in penal legislation and sentencing policy in many other European Countries. This makes it more difficult for the Strasbourg Court because it can hardly condemn a jurisdiction that is 'beyond the average'. Moreover, as the Court seems to be in favour of reducing long-term imprisonment, it is provisionally not to be expected that it will adopt a critical approach towards supervision as an alternative form of punishment.

By discussing the execution of the (restrictive) conditions that can potentially be imposed in the context of supervision, we come to the third 'entrance' for assessing the supervisory safety measure from a human rights perspective. This relates to the complex legal possibility that supervision is that restrictive and far-reaching, given the degree and intensity of the conditions imposed on the offender, that it does not apply so much to the test of Article 2 Fourth Protocol but rather to the more stringent test of Article 5 ECHR. This possibility stems from case law of the ECtHR, ${ }^{93}$ applied by the courts in the Netherlands. ${ }^{94}$ However, it is difficult to predict in advance when supervision in a certain case may fall within the scope of Article 5 ECHR. One might expect that a notification order, to report to the Probation Services, may as such not fall within this scope, in contrast perhaps to (combinations of) more restrictive conditions such as life-long restraining orders. With regard to the new safety measure, this may very well be the case. As mentioned in Section 3, there are some possibilities where this supervisory measure could turn into the deprivation of the offenders' liberty, e.g. because of a condition to participate in treatment with clinical admission, or because of the legal effect of alternative deten-

91. See e.g. Dutch Supreme Court 27 March 2012, ECLI:NL:HR 2012:BV6996, with regard to the conditional supervisory TBS measure.

92. Court of Appeal Den Haag 30 July 2014, ECLI:NL:RBDHA:2014:9411.

93. See e.g. ECtHR, Guzzardi v. Italy, Applic. No. 7367/76, 6 November 1980; see further Bleichrodt et al., above n. 60.

94. See e.g. Court of Appeal Arnhem-Leeuwarden 9 January 2014, ECLI:NL:GHARL:2014:67 and Court of Appeal Arnhem-Leeuwarden 20 February 2014, ECLI:NL:GHARL:2014:1669. 
tion for a maximum duration of six months whenever a condition is breached. Surely those conditions have to meet the requirements of Article 5 ECHR. Consequently, it may be possible that, in a certain case, the complete set of imposed conditions is so restrictive that what seems to be (only) restriction of liberty in practice amounts to deprivation of liberty.

Knowing the legal difficulties and the importance of this assessment with regard to Article 5 ECHR, the Government has given quite some attention to it in their prelegislative justification. This was obviously prompted by recent case law of the ECtHR concerning the German safety measure 'nachträgliche Sicherungsverwahrung', a modality of preventive detention, which to the opinion of the Court constituted a violation of Articles 5 and 7 ECHR. ${ }^{95}$ The main problem concerning this preventive detention measure was twofold. First, the lack of a causal link between the preventive detention and a specific offence, required by Article 5(1)a, and second, the fact that this measure was not based on a conviction within the meaning of that provision, required by Article 5(1)c. To our knowledge, when the Dutch safety measure enters into force, it would not constitute a violation of the convention on these restriction grounds. First, the aforementioned possibility of alternative detention whenever a condition is breached is likely to involve lawful detention under Article 5(1)a because that detention is directly linked to a conviction by a competent court. The same might be true for the second, and equally aforementioned, possibility of mandatory participation in treatment with clinical admission. Yet, this possibility does have to meet the additional requirements stated by the ECtHR in order to be the 'lawful detention of a person of unsound mind' within the meaning of Article 5(1)e. ${ }^{96}$

In our opinion, the proposed measure could generally withstand the test of Article 5 ECHR. First, because of the twofold sentencing procedure the Government proposes - the execution does not involve additional punishment - and the fact that both the decision to impose the supervisory safety measure and the decision to actually execute the imposed measure are made by an independent court, while both decisions can be reviewed in appeal. That in itself is a strong legal safeguard, besides various other safeguards such as the procedure in which the offender may ask the court to change or terminate the conditions imposed upon him, as well as the extension procedure that automatically involves a periodic judicial review of the necessity of (further extending) the measure. ${ }^{97}$ Yet, regarding the

95. ECtHR, M. v. Germany, Applic. No. 19359/04, 17 December 2009 and ECtHR, Jendrowiak v. Germany, Applic. No. 30060/04, 14 April 2011; see further J. Kinzig, 'The ECHR and the German System of Preventive Detention: an Overview of the Current Legal Situation in Germany', in M. Caianiello and M.L. Corrado (eds.), Preventing Danger: New Paradigms in Criminal Justice (2013), 71, as well as the contribution of Meier in this special issue.

96. See e.g. ECtHR, Winterwerp v. the Netherlands, Applic. No. 6301/73, 24 October 1979.

97. Such as required in ECtHR, $X$ v. UK, Applic. No. 7215/75, 5 November 1981. new measure as a whole we do have serious doubts concerning the requirements of proportionality and necessity, as elaborated on before. Both the questions whether the measure will meet these requirements and whether the conditions that would actually be imposed on the offender would be that stringent and grave that they could not meet the (other) requirements of Article 5 ECHR, are to be answered by the judiciary. Moreover, another bottleneck might be the fact that as a result of the twofold sentencing procedure - whereby the decision making on the imposition and the execution of the measure is separated in time, which could easily amount to over ten years because the equally imposed prison sentence or TBS safety measure has to be fully executed first - the offender cannot foresee at the time of his conviction whether the imposed supervisory safety measure will actually be executed or not, nor can he foresee the specific content of the measure or by which behaviour he may influence the extension decision. Moreover, in so far as this latter unforeseeability relates to a proper treatment, the offender is highly dependent on the Government. Therefore, although we would not argue that Article 5 ECHR is seriously at stake, once the law is implemented it may be assessed by the (national) courts as an infringement of the requirement of foreseeability as derived from Article 7 ECHR.

The fourth and in our view perhaps most important or at least most fundamental 'entrance' for human rights assessment might be found in another direction., Article 10(3) ICCPR - a binding provision in the Netherlands calls for a prison system that provides in treatment of detainees, which is primarily aimed at 'reformation and social rehabilitation'. Reading this provision as part of the guarantee for humanity in para. 1, one might argue that, with this provision, a right to reformation and social rehabilitation is guaranteed as a human right, ${ }^{9}$ which includes a much more profound and broader concept than the Dutch reducing reoffending concept of rehabilitation. ${ }^{99}$ At least, it contains a strong urge for member states to aim for a true rehabilitation and a full return to society. This concept calls upon member states to accept this aim as a positive obligation for their sanction system including the execution of custodial sanctions. Moreover, the ECtHR has stated that a true, social rehabilitation is a mandatory factor in penal policy. ${ }^{100}$ However, as disappointing as it might be, in the same case law, the Court has added that 'the Convention does not guarantee, as such, a right to rehabilitation'. Yet, within the framework of the Council of Europe,

98. J. de Lange and P.A.M. Mevis, 'De beoordeling van de menswaardigheid van detentiesituaties', Sancties 157 (2003).

99. Struijk (2011), above n. 3; Struijk (2015), above n. 20; M.M. Boone, 'Judicial Rehabilitation in the Netherlands: Balancing between Safety and Privacy', 3 European Journal of Probation 63 (2011) and S. Meijer, 'De opmars en evolutie van het resocialisatiebegrip', 9 Delikt en Delinkwent 688 (2015).

100. See e.g. ECtHR Khoroshenko v. Russia, Applic. No. 41418/04, 30 June 2015, para. 121; ECtHR Harakchiev and Tolumov v. Bulgaria, Applic. No. $15018 / 11$ and 61199/12, 8 July 2014, paras. 243-6, and ECtHR Vinter v. UK, Applic. No. 66069/09, 130/10 and 3896/10, 9 July 2013, paras. 111-6. See e.g. Meijer (2015), above n. 99. 
soft rules do incite a right to rehabilitation, e.g. Article 6 European Prison Rules. Moreover, in many cases concerning (life-)long imprisonment, the ECtHR stresses the prospect of rehabilitation as an important legal aim and principle. ${ }^{101}$ In this approach of the Court, one can clearly read a dedication if not an obligation towards a long series of efforts for an offender's full return into society. In our view, this approach does not only relate to imprisonment as such but moreover and mainly to the 'in between' period of conditional release as well.

How does this relate to the Dutch law striving for indeterminate supervision? Our first objection is that, if the new supervision modalities are to be characterised first and foremost as a mechanism aiming to control the offenders' conduct, this aim is by far not enough to regard these modalities as part of social rehabilitation in its true form. The second objection is that these supervision modalities, especially those of (life-)long duration, effectively hamper social rehabilitation. As we already argued in Sections 3 and 4, research shows that even if there might be an argument for supervision beyond the currently possible duration, the mere emphasis on control is not effective and thus not legitimate.

Concerning the specific content of the Dutch law, the same applies for the modality of supervision after a prison sentence. In this respect, the justification by the Government is that even if the imposed sanction is legally ending, the aim of preventing recidivism may imply that the offender's return to society is not permitted without ongoing control. This justification is highly debatable though, because if an unconditional return to society is not accepted as a possibility, in the end the execution of imprisonment as such is disputed. Moreover, one might seriously wonder whether in this line of reasoning such a control-oriented supervision can be legitimised in terms of social rehabilitation. One could even raise the question as to what extent these supervision modalities actually lean on a conviction for a criminal offence. Finally, because such a control-oriented system persists in excluding offenders, it is a wilful created handicap for true 'anthroposophic' rehabilitation of the offender 'into one of us'. Consequently, in our view such a supervision system may very well come up for discussion with the ECtHR.

The same objections and concerns are true with regard to the new independent supervisory safety measure. Although the judge would impose this sanction together with a conviction for the offence, ensuring a clear and causal link between the supervision and a specific offense, its execution will take place in an unforeseen time after the execution of an equally imposed prison sentence or TBS measure. Thus, it can be unmasked as another modality aiming for ongoing control after the execution of an initial punishment as proportionate reaction to the offence. The fact that the supervisory safety measure is applied simultaneously with the punishment is a mere pretext to avoid a breach of Article 5

101. See e.g. ECtHR Vinter v. UK and ECtHR Khoroshenko v. Russia.
ECHR, influenced by the German case law regarding the preventive detention modality of 'nachträgliche Sicherungsverwahrung'. This procedural provision can and may not hide the true character of the new Dutch measure: the perilous non-acceptance of an offender's unconditional return into society.

In this respect, only the last part of the law - preventive supervision after a TBS measure - might be criticised less, yet only because and in so far this TBS measure is aimed at treatment and influencing the offender's behaviour instead of control. If the offender's restriction of liberty instead of his deprivation of liberty is thought to be sufficient to meet this aim as well as to reduce his risk, then this new post-custodial supervision modality more or less entails a variation of the already existing concept of the conditional TBS measure. But again only if the execution and the treatment are based on the prospect of true rehabilitation instead of mere control.

\section{Conclusion}

Central to this article is the currently enacted law on post-custodial release supervision in the Netherlands, focusing on a threefold increase in the post-custodial supervision of dangerous (sex) offenders. All three parts of the law could result in life-long supervision of these offenders. The first two parts do so by extending the possibilities of supervision as part of the conditional release after the execution of either a prison sentence or a TBS safety measure. The third part, though, introduces an independent supervisory safety measure, which is to be executed after either a prison sentence or a TBS measure is conditionally or unconditionally ended. Because of the profound change that such a new independent safety measure will trigger the Dutch penal sanction system, we have particularly analysed and assessed the latter part, both in relation to the Dutch sentencing theory and the existing sanctions in the Dutch penal law system, as to the legal criteria resulting from a human rights framework such as proportionality and LRM. Resulting from that analysis, we come to the main conclusion that the new independent supervisory safety measure is not legitimate (yet). The main argument is not so much a clear violation of the human rights framework - although the imposed conditions may be that restrictive and severe that they could amount to a violation under Article 5(4) ECHR, and the actual content of the measure may furthermore be so unforeseeable that it could amount to an infringement of Article 7 ECHR - but rather the fact that the need for this measure is still unclear.

This has much to do with the current lack of (empirical evidence of) the necessity of this possibly life-long supervisory measure, the lack of legitimising supervision 'gaps' in the existing penal sanction system, the fact that the other parts of the discussed law equally result in a possibility of life-long supervision of the same offender category, the lack of any individual interest that could 
legitimise the imposition and execution of this preventive safety measure, the much broader European penal concept of 'social rehabilitation' to which the Dutch concept should comply but currently fails to do so, and finally, the lack of clear criteria in the legal framework for both determining the initial dangerousness of the offender and deciding whether the supervisory measure needs to be extended and how the offender could influence this decision. All in all, it is premature to adopt such a drastic penal law while the need and legitimacy have not yet been demonstrated. The call for this possibly life-long supervisory safety measure seems mainly aimed at defusing the public controversy and preventing an (alleged) dangerous (ex-)offender from recidivism, than actually investing in a true and social rehabilitation of this offender.

Nevertheless, as said, the draft law has indeed been enacted by Dutch Parliament recently and is expected to take effect in the summer of 2016. It is highly likely that the fact that new tragic events continue to occur with (conditionally) released offenders committing violent crimes not only strengthened the call from politics and society to increase the legal possibilities for life-long supervision, but also played an important part in the Democratic voting. Without any judicial legitimacy, the widely held motto seems to be 'better safe than sorry'. In our view, this is by no means enough to justify such a severe penal sanction. Moreover, when this law will take effect, we have strong concerns that - triggered by a culture of fear and public security - pressure will be exercised upon Dutch judiciary to impose and execute the supervisory safety measure upon offenders rather for normative than scientific reasons. One can only hope that judiciary will once again demonstrate their independent and critical judgement by weighing both the public interests and the individual's interests. Only such a judgement, especially concerning both the execution and the extension of this supervisory measure, could prevent a counterproductive effect of the measure whereby the (ex-)offender grows so socially isolated that he becomes (only more) dangerous. To 'support' Dutch judiciary in this, it is necessary that the ECtHR will develop the concept of social rehabilitation further, in order to be an effective legal safeguard against - at least - an overuse of the new supervision modalities. 